\title{
Osteosíntesis maxilofacial con materiales reabsorbibles
}

\section{Maxillofacial osteosynthesis with resorbable material}

\section{J.L. López-Cedrún Cembranos}

Resumen: La popularización de la combinación de ácidos poliláctico y poliglicólico ha hecho que estos nuevos materiales se utilicen cada vez más en la osteosíntesis maxilofacial, no solo en su aplicación pediátrica, sino también en adultos. Aunque todavía presentan algunas desventajas en relación con el titanio, como la mayor incomodidad de uso y el coste económico, la experiencia acumulada demuestra que es una alternativa válida a la osteosíntesis con titanio en la mayoría de las situaciones clínicas.

En este artículo se analizan las características y cualidades de los materiales reabsorbibles empleados en osteosíntesis maxilofacial. Así mismo, se discuten las ventajas y desventajas de ambos tipos de osteosíntesis y se documentan las indicaciones actuales de la osteosíntesis reabsorbible basándonos en nuestra experiencia y en la revisión de la literatura.

Palabras clave: Osteosíntesis reabsorbible; Acido poliláctico; Acido poliglicólico; Osteotomía.

\begin{abstract}
Resorbable plates and screws composed of polylactic and polyglycolic acid, as internal fixation devices have gained widespread use during recent years in pediatric and also adult patients. Although these materials show some disadvantages when compared with titanium plates, such as discomfort and economical cost, accumulated experience shows that resorbable ostheosynthesis is a reliable alternative to the titanium osteosynthesis used in most clinical cases. In this paper we analyze the main characteristics of resorbable materials used in maxillofacial osteosynthesis. We discuss the advantages and disadvantages of both types of osteosynthesis and the indications for resorbable ostheosynthesis at the present time, based on our experience and on a revision of the literature.
\end{abstract}

Key words: Resorbable osteosynthesis; Polylactic acid; Polyglycolic acid; Osteotomy.

Jefe de Servicio.

Servicio de Cirugía Oral y Maxilofacial.

Complejo Hospitalario Universitario Juan Canalejo, La Coruña, España

\section{Correspondencia:}

Complejo Hospitalario Universitario Juan Canalejo

C/ Xubias de Arriba, 84

15006 A Coruña

E-mail: lopezcedrun@centromaxilofacial.com 


\section{Introducción}

Sin duda la osteosíntesis rígida ha supuesto uno de los mayores avances en el campo de la cirugía maxilofacial moderna. El titanio ha demostrado sus excelentes cualidades a lo largo ya de 25 años. Sin embargo, la aparición y popularización de la combinación de ácidos poliláctico y poliglicólico, ha hecho que estos nuevos materiales se utilicen cada vez más. Pocas dudas quedan ya en su aplicación pediátrica, pero todavía suscita controversia su utilización en cirugía maxilofacial de adultos. Y la pregunta que nos hacemos es: ¿puede en estos momentos la osteosíntesis reabsorbible reemplazar al titanio en la fijación ósea craneomaxilofacial en pacientes adultos?

Para contestar a la pregunta primero hay que señalar que además de las bondades inherentes a la osteosíntesis con titanio, también, se le atribuyen desventajas que incluyen la palpabilidad inaceptable, la exposición intraoral, la migración pasiva de los tornillos y placas, ${ }^{1}$ y la distorsión de futuras imágenes de RM y TC, ${ }^{2}$ además de la interferencia con el tratamiento radioterápico. ${ }^{3}$ También se ha publicado la migración y depósito de partículas de titanio en los tejidos blandos y los ganglios linfáticos. ${ }^{4}$

La primera referencia a la osteosíntesis reabsorbible se debe a Kulkarni y cols, ${ }^{5}$ que propusieron en 1966 la utilización de ácido poliláctico como implante quirúrgico. La primera publicación del uso de material reabsorbible en la fijación del esqueleto facial se debe a Cutright y cols, ${ }^{6}$ en un estudio experimental, aunque en esta época no se llegaron a comercializar estos biomateriales. En los años 80 se realizaron experimentos con placas y tornillos de PLLA con resultados prometedores que condujeron a varios ensayos clínicos. ${ }^{7-10}$

Los materiales bioreabsorbibles más utilizados en cirugía craneomaxilofacial son ácidos poly-alpha-hydroxy de alto peso molecular: ácido poliláctico (PLA), ácido poliglicólico (PGA), polidioxanona (PDS), y sus copolímeros. Estos ácidos se degradan a través de hidrólisis simple en el medio acuoso de los tejidos vivos. Primero se disuelven en pequeños fragmentos que son fagocitados por los macrófagos y las células gigantes. Los productos resultantes de la degradación del PLA y del PGA son metabolizados en dióxido de carbono y agua y son eliminados en la respiración.1,9 Los productos del PDS se excretan primariamente en la orina. La reabsorción completa varía entre 6 meses y 4 años dependiendo de la composición, aunque la tensión la pierden meses antes.1,11

El objetivo de este trabajo es analizar las cualidades de los materiales reabsorbibles empleados en osteosíntesis maxilofacial, discutir las ventajas y desventajas de los mismos con respecto al titanio y documentar las indicaciones actuales de la osteosíntesis reabsorbible basándonos en nuestra experiencia y en la revisión de la literatura.

\section{Características de los materiales reabsorbibles}

La mayoría de los materiales de osteosíntesis reabsorbible están compuestos por dos copolímeros reabsorbibles (ácido poliláctico y ácido poliglicólico) en una proporción variable que condicionará

\section{Introduction}

Rigid osteosynthesis has supposed one of the greatest advances in the field of modern maxillofacial surgery. Titanium has demonstrated excellent qualities over 25 years. However, the appearance and widespread use of combinations of polylactic and polyglycolic acids has meant that these new material are used more frequently. Few doubts remain as to its application in pedriatrics, but there is still some controversy as to its use in maxillofacial surgery in adults. And we should therefore ask. Can resorbable osteosynthesis at the moment replace titanium in craniomaxillofacial bone fixation in adult patients?

In order to answer this question we first have to stress that, in addition to the inherent advantages of osteosynthesis with titanium, disadvantages have been attributed to it including; unacceptable palpability, intraoral exposure, passive migration of the screws and plates, 1 and the distortion of future NMR and CT2 images, in addition to interferences with radiotherapy treatment. ${ }^{3}$ Titanium particle deposits and migration to soft tissue and lymphatic nodes has also been described. ${ }^{4}$

The first reference to resorbable osteosynthesis was by Kulkarni and cols, ${ }^{5}$ who in 1966 proposed the use of polylactic acid as a surgical implant. The first publication on the use of absorbable materials for fixing the facial skeleton belongs to Cutright and cols 6 and it was an experimental study, although in that era biomaterials were not commercialized. In the 80s experiments were carried out with PLLA plates and screws with promising results and which lead to various clinical trials. . $^{710}$

The bioresorbable materials that have been used most in craniomaxillofacial surgery are poly-alpha-hydroxy acids that have a high molecular weight: polylactic acid (PLA), polyglycolic acid (PCA), polydioxane (PDS) and their copolymers. These acids are degraded through simple hydrolysis in the aqueous medium of living tissue. They are first dissolved in small fragments, which are phagocytosed by macrophages and by giant cells. The resulting products of the PLA and PGA degradation are metabolized in carbon dioxide and water and they are eliminated through repiration.1,9 The products of PDS are excreted primarily in the urine. Complete resorption varies between 6 months and 4 years depending on the composition, although tension is lost several months before. ${ }^{1,11}$

The object of this work is to analyze the qualities of the resorbable materials used in maxillofacial osteosynthesis, to discuss their advantages and disadvantages with regard to titanium, and to document the current indications for resorbable osteosynthesis based on our experience and a revision of the literature.

\section{Characteristics of resorbable materials}

Most of the resorbable osteosynthesis material is composed of two resorbable copolymers (polylactic acid and polyg- 
resistencia frente a tiempo de reabsorción, según el que predomine. La degradación ocurre en dos fases, primero a través de hidrólisis y después mediante la fagocitosis de los fragmentos por los macrófagos que convierte los restos de polímeros en agua y dióxido de carbono. Algunos de los factores que influyen en la tasa de degradación son la identidad química del polímero, su peso molecular, la proporción cristalino/amorfo y el tamaño y forma del implante. ${ }^{1,12}$ Alterando las propiedades de los copolímeros mediante la selección adecuada de la identidad y proporción de los monómeros, las características del comportamiento del implante puede manipularse aumentando su resistencia (L-láctico), la absorción (glicóliCo), o la maleabilidad (D-láctico).1,7,12

Algunas compañías también añaden en la composición el carbonato de trimetileno, que proporciona maleabilidad a la placa y mejora las propiedades de manejo de las mismas (www.inion.com, datos no publicados). Este compuesto ha sido utilizado en la composición de la sutura reabsorbible Maxon ${ }^{\circledR}$, que está formada por un copolímero de glicólico y carbonato de trimetileno, constituyendo este último el 32,5\% del peso. ${ }^{13}$

A continuación vamos a resumir las características más destacadas de los polímeros empleados en la composición de las placas y tornillos reabsorbibles: 1,9,10,14

Ácido poliláctico (PLA). Tiene dos enantiómeros: ácido L-láctico y ácido D-láctico. Clínicamente se utiliza como ácido poli-L-láctico puro (PLLA) y como copolímero de ácido poli-D,L-láctico (PDLLA). El PDLLA racémico contiene 50\% de ambos enantiómeros (50L:50D) y muestra una fuerza mecánica moderada.

Ácido poli-L-láctico (PLLA). Posee las mejores propiedades de fortaleza, por lo que es el poliláctico más usado. Esta fortaleza la pierde lentamente, solo el $25 \%$ en los 3 primeros meses y el $100 \%$ al año, pero su biodegradación total requiere 4-5 años. Se ha mostrado muy biocompatible en ensayos clínicos, pero produce frecuente inflamación debido a la alta cristalinidad. ${ }^{15}$

Ácido poli-DL/L-láctico $(P(L / D L) L A)$. Actualmente se prefiere utilizar copolímeros de ácido L-láctico y ácido D-láctico en vez de PLLA puro ya que presentan propiedades mecánicas adecuadas (resistencia mecánica durante 3-4 meses) y son amorfos. La degradación ocurre en dos fases y de esta manera la tolerancia de los tejidos no es excedida.

Acido poliglicólico (PGA). El poliglicólico autoreforzado muestra las mejores propiedades de resistencia iniciales, similares al acero inoxidable, que se pierden a las 6 semanas, y se reabsorbe completamente en menos de un año. ${ }^{16}$ Sin embargo, aparecen reacciones adversas en más del $60 \%$ de los casos debido a la rápida producción de restos de polímeros que excede la capacidad de los tejidos. ${ }^{17}$

Debido a las reacciones adversas, el PGA y el PLLA puros ya no se utilizan y se prefiere utilizar copolímeros de ambos en diferentes proporciones solo en pacientes pediátricos ya que en éstos no acontecen reacciones adversas. Están disponibles comercialmente en proporciones 82:18 (Lactosorb $^{\circledR}$ ) y 80:20 (Biosorb PDX ${ }^{\circledR}$ ). Es amorfo, conserva el $70 \%$ de su resistencia inicial durante 6-8 semanas y se degrada en un año. ${ }^{11}$ Puede producir inflamación discreta en adultos causado por el PGA, no detectada en niños.

Carbonato de trimetileno (TMC). Proporciona maleabilidad. También aporta ventajas en el manejo de la placa, como poder mode- lycolic acid) in a variable proportion, which will condition resistance as opposed to resorption time, according to which one dominates. Degradation occurs in two phases, first through hydrolysis and then through phagocytosis of the fragments by macrophages that converts the rest of the polymers in water and carbon dioxide. Some of the factors that influence the rate of degradation are, the chemical identity of the polymer, its molecular weight, the crystalline/amorphous proportion, and the size and form of the implant.1,12 By changing the properties of the copolymers through adequate selection of the identity and proportion of the monomers, the behavioral characteristics of the implant can be manipulated increasing its resistance (L-lactic), absorption (glycolic), or malleability (D-lactic). 1,7,12

Some companies also add trimethylene carbonate to the composition, which gives the plate more malleability and improves their handling properties (www.inion.com unpublished data). This compound has been used in the composition of the Maxon resorbable suture, ${ }^{8}$ which is formed by a copolymer of glycolic, and trimethylene carbonate, the latter representing $32.5 \%$ of its weight. ${ }^{13}$

Next, we will sum up the characteristics that stand out of the polymers used in the composition of resorbable plates and screws. 1,9,10,14

Polylactic acid (PLA). It has two enantiomers: L-lactic acid and D-lactic acid. It is used clinically as pure poly-L-lactic acid and as a copolymer of poly-D, L-lactic acid (PDLLA). The racemic PDLLA contains $50 \%$ of both enantiomers (50L:50D) and it demonstrates a moderate mechanical force.

Poly-L-lactic acid (PLLA). This has the best properties regarding strength, and it is the polymer which is most used. Its strength is lost slowly, only 25\% during the first three months and $100 \%$ after a year, but its complete biodegradation requires $4-5$ years. It has been shown to be very biocompatible in clinical trials, although inflammation is frequently produced due to high crystallinity. ${ }^{15}$

Poly- DL/L-Lactic acid $(P(L / D L) L A)$. Currently the use of the copolymers L-lactic acid and D-lactic acid is preferred to pure PLLA, as they have adequate mechanical properties (mechanical resistance for more than 3-4 months) and are amorphous. Degradation occurs in two phases and in this way tissue tolerance is not exceeded.

Polyglycolic acid (PGA). Self-reinforced polyglycolic [acid] has been demonstrated as having the best properties for initial resistance, similar to stainless steel, which is lost at 6 weeks, and reabsorbed completely in under a year. ${ }^{16} \mathrm{How}$ ever, in more than $60 \%$ of cases adverse reactions appear due to the rapid production of polymer remains that exceeds tissue capacity. ${ }^{17}$

Due to adverse reactions, pure PGA and the PLLA are not used and copolymers of both of them are preferred in different proportions in pediatric patients as no adverse reactions appear. They are available commercially in a ratio of 82:18 (Lactosorb) and 80:20 (Biosorb PDX). It is amorphous, conserving $70 \%$ of its initial resistance for $6-8$ weeks and it 
larse al enfriarse después del calentado inicial, así como necesitar menor temperatura del dispositivo de calentamiento $\left(55^{\circ}\right)$.

Otros compuestos reabsorbibles. Caprolactona $(C L)$ y Polidioxano (PDS). Aunque se ha descrito su utilización, no se emplean en la composición de las placas actuales. El polidioxano presenta propiedades mecánicas modestas y se degrada completamente en 6 meses. No se han descrito reacciones adversas en tejidos blandos, aunque puede ocasionar reacciones osteolíticas pasajeras.

Polímeros autoreforzados. Törmälä, ${ }^{18}$ desarrolló las técnicas de autorreforzado en la fabricación de los componentes biodegradables. El autorrefuerzo supone una importante mejora de la propiedades mecánicas de los materiales reabsorbibles ya que una parte de la estructura del polímero se trasforma en fibras reforzadas durante el proceso de manufactura. Serlo y cols, ${ }^{19}$ han comprobado que las placas SR-PLLA tienen una elasticidad similar a la del hueso; por el contrario, la del metal es 5-10 veces mayor.

En estudios experimentales, ${ }^{20}$ estos polímeros han mostrado su superioridad frente a otros materiales. Además, pueden esterilizarse con rayos gamma. La experiencia clínica con estos polímeros durante más de 10 años ha mostrado buenos resultados. ${ }^{21}$

En la Tabla 1 se resumen las características principales de los materiales de osteosíntesis reabsorbible comercializados en España. La mayoría son combinaciones de poli-D-láctico o poliglicólico con poli-L-láctico. Esto reduce la cristalinidad, que enlentece la reabsorción y es la causa principal de las reacciones adversas que se documentaban inicialmente.

\section{Indicaciones actuales de la osteosíntesis reabsorbible}

Las tres aplicaciones básicas de la osteosíntesis maxilofacial son: Traumatología, Cirugía Ortognática y Cirugía Craneofacial. Nuestra experiencia hasta el momento actual en la osteosíntesis reabsorbible se basa en una serie de 80 pacientes intervenidos de cirugía craneofacial (29 pacientes), cirugía ortognática (31 pacientes) y trauma craneofacial (20 pacientes). Quizá las fracturas ideales para comparar la osteosíntesis metálica con titanio y la reabsorbible sean las ocasionadas por las osteotomías utilizadas en cirugía ortognática; se trata de trazos de fractura estandarizados y reproducibles en general en todos los pacientes.

Las osteotomías que hemos empleado correspondieron a Le Fort I (en un fragmento o segmentado en dos o en cuatro fragmentos), osteotomía sagital mandibular y mentoplastia. Más de la mitad de los pacientes corresponden a cirugía bimaxilar. En el maxilar hemos utilizado 4 miniplacas 2.0 ( $4 \mathrm{~L}$ o a veces $2 \mathrm{~L}$ y 2 rectas); en la mandíbula 3 ó 4 tornillos 2.4 ó 2.8 en cada lado y en el mentón miniplacas 1.5 (Figs. 1-3).

Uno de los aspectos más controvertidos con la utilización de osteosíntesis reabsorbible es la estabilidad, habiéndose publicado casos que necesitaron reintervención quirúrgica para estabilizar el maxilar. ${ }^{22}$ Clínicamente, es evidente que la fijación es menor que con titanio y de hecho en las osteotomías maxilares segmentadas el maxilar presenta movilidad, siendo por lo tanto una osteosíntesis semirígida; por el contrario, no se ha observado movilidad de los segmentos mandibulares en ningún caso. En nuestra serie nin- degrades after a year. ${ }^{11}$ It can produce discrete inflammation in adults caused by the PGA that is not detected in children.

Trimethylene carbonate (TMC). It provides malleability. It also has advantages for plate manipulation, as it can be molded on cooling after being heated initially, as the heating device requires less temperature. (55ㅇ).

Other resorbable components. Caprolactone $(C L)$ and Polydioxanone (PDS). Even though its use has been described, it has not been used in the composition of the latest plates. Polydioxane has modest mechanical properties as it degrades at 6 months. Adverse reactions have not been described in soft tissue, although transient osteolytic reactions may occur.

Self-reinforced polymers. Törmälä18 developed self-reinforcing techniques for the manufacture of biodegradable techniques. Self-reinforcement represents an important improvement in the mechanical properties of resorbable materials, as one part of the polymer structure is transformed into reinforced fibers during the manufacturing process. Serlo and cols ${ }^{19}$ verified that the SR-PLLA plates have an elasticity similar to that of bone; metal ones were, on the contrary, 5-10 times greater.

In experimental studies ${ }^{20}$, these polymers have shown their superiority over other materials. In addition they can be sterilized with gamma rays. Clinical experience with these polymers has shown good results for more than 10 years. ${ }^{21}$

Table 1 gives a summary of the principal characteristics of resorbable osteosynthesis material commercially available in Spain. The majority are combinations of poly D-lactic, or polyglycolic with poly-l-lactic combinations. This reduces crystallization, which makes resorption slower and is the principal cause of the adverse reactions that were first documented.

\section{Current indications for resorbable osteosynthesis}

The three basic applications for maxillofacial osteosynthesis are: Traumatology, Orthognathic surgery and Craniofacial surgery. Our experience to date of resorbable osteosynthesis is based on a series of 80 operated patients having craniofacial surgery (29 patients), orthognathic surgery (31 patients) and craniofacial trauma (20 patients). Perhaps the fractures that are ideal for comparing metallic osteosynthesis using titanium, with resorbable osteosynthesis are those that occur as a result of osteotomies performed in orthognathic surgery; these are standard fractures lines that are reproduced in all patients.

The osteotomies performed correspond to Le Fort 1 (in one fragment or segment, or in two or four fragments), sagittal osteotomies of the mandible and mentoplasties. More than half the patients correspond to bimaxillary surgery. In the maxilla we have used 42.0 miniplates (4 L shaped or sometimes $2 L$ shaped and 2 straight ones); in the mandible 3 or 42.4 or 2.8 screws in each side, and 1.5 miniplates for the chin (Figs. 1-3). 
Tabla 1. Características principales de los sistemas de osteosíntesis maxilofacial reabsorbible comercializados en España

\begin{tabular}{|c|c|c|c|c|}
\hline Producto-marca & Composición & Propiedades Mecánicas* & Tiempo de reabsorción & Sistemas \\
\hline $\begin{array}{l}\text { Lactosorb }^{\circledR} \\
\text { Walter Lorenz }\end{array}$ & P(L/DL)LA 82L:18DL & 6-8 semanas & 9-15 meses & $\begin{array}{l}\text { Sistema } 1,5 / 2,0 \text {. Espesor } 0,6 \mathrm{~mm} \\
\text { Tornillos } 1,5,2,0,2,5\end{array}$ \\
\hline \multicolumn{5}{|l|}{ BioSorb FX ${ }^{\oplus}$} \\
\hline LINVATEC & $\begin{array}{l}\text { SRP(L/DL)LA 70L:30DL } \\
\text { autorreforzado }\end{array}$ & 18-36 semanas & 2-4 años & $\begin{array}{l}\text { Sistema } 1,5 / 2,0 \\
\text { Sistema } 2,0 / 2,4 \\
\text { Espesor } 0,6 \mathrm{~mm}\end{array}$ \\
\hline $\begin{array}{l}\text { BioSorb PDX } \\
\text { LINVATEC }\end{array}$ & $\begin{array}{l}\text { PLGA 80L:20G } \\
\text { autorreforzado }\end{array}$ & 6-8 semanas & $1-3$ años & $\begin{array}{l}\text { Sistemas } 1,5 \text { y } 2,0 \\
\text { Espesor } 0,8 \mathrm{~mm}\end{array}$ \\
\hline $\begin{array}{l}\text { Resorb X } \\
\text { MARTIN }\end{array}$ & PDLLA 50L:50DL & 8-10 semanas & 12 meses & $\begin{array}{l}\text { Sistema único de miniplacas } \\
\text { Tornillos } 1,6,2,1,2,4 \\
\text { Mallas } 0,3-0,6-1 \mathrm{~mm} \text { espesor }\end{array}$ \\
\hline $\begin{array}{l}\text { PolyMax Classic } \\
\text { SYNTHES }\end{array}$ & P(L/DL)LA 70L:30DL & semanas & $\begin{array}{l}70 \% \text { en } 6 \text { meses } \\
100 \% \text { en } 2 \text { años }\end{array}$ & $\begin{array}{l}\text { Sistemas } 1,5 \text { y } 2,0 \\
\text { Espesor } 0,5-1,2 \mathrm{~mm}\end{array}$ \\
\hline $\begin{array}{l}\text { PolyMax Rapid } \\
\text { SYNTHES }\end{array}$ & PLGA 85L:15G & 8 semanas & 100\% en 1 año & $\begin{array}{l}\text { Sistemas } 1,5 \text { y } 2,0 \\
\text { Espesor } 0,5-1,2 \mathrm{~mm}\end{array}$ \\
\hline DeltaSystem $^{\circledR}$ & PLLA-PDLA-PGA & 8 semanas & 24-30 meses & Sistemas 1,7 y 2,2 \\
\hline STRYKER\&LEIBINGER ${ }^{\circledR}$ & $85: 5: 10$ & & & Espesor $1 \mathrm{~mm}$ \\
\hline Inion CPS Baby ${ }^{\circledR}$ & PLLA-PGA-TMC & 6-9 semanas & 1-2 años & CPS Baby 1,5 \\
\hline INION & $\%$ no facilitados & & & Espesor $0,8 \mathrm{~mm}$ \\
\hline $\begin{array}{l}\text { Inion CPS Adultos } \\
\text { INION }\end{array}$ & $\begin{array}{l}\text { PLLA-PDLLA- TMC } \\
\% \text { no facilitados }\end{array}$ & 9-14 semanas & $2-4$ años & $\begin{array}{l}\text { CPS Adultos 1,5, 2,0, 2,5 } \\
\text { Espesor } 1 \mathrm{~mm}\end{array}$ \\
\hline
\end{tabular}

Table 1. Main characteristics of the resorbable maxillofacial systems marketed in Spain

\begin{tabular}{|c|c|c|c|}
\hline Product-make & composition & Mechanical propertie* & Resorption on time \\
\hline $\begin{array}{l}\text { Lactosorb }^{\circledR} \\
\text { Walter Lorenz }\end{array}$ & P(L/DL)LA 82L:18DL & 6-8 weeks & 9-15 months \\
\hline BioSorb FX ${ }^{\circledast}$ & & & \\
\hline LINVATEC & $\begin{array}{l}\text { SRP(L/DL)LA 70L:30DL } \\
\text { reinforced }\end{array}$ & 18-36 weeks & $2-4$ years \\
\hline $\begin{array}{l}\text { BioSorb PDX } \\
\text { LINVATEC }\end{array}$ & $\begin{array}{l}\text { PLGA 80L:20G } \\
\text { reinforced }\end{array}$ & 6-8 weeks & $1-3$ years \\
\hline $\begin{array}{l}\text { Resorb X } \\
\text { MARTIN }\end{array}$ & PDLLA 50L:50DL & $8-10$ weeks & 12 months \\
\hline $\begin{array}{l}\text { PolyMax Classic }{ }^{\circledast} \\
\text { SYNTHES }\end{array}$ & P(L/DL)LA 70L:30DL & weeks & $\begin{array}{l}70 \% \text { in } 6 \text { months } \\
100 \% \text { in } 2 \text { years }\end{array}$ \\
\hline $\begin{array}{l}\text { PolyMax Rapid } \\
\text { SYNTHES }\end{array}$ & PLGA 85L:15G & 8 weeks & $100 \%$ in 1 year \\
\hline $\begin{array}{l}\text { DeltaSystem }^{\circledR} \\
\text { STRYKER\&LEIBINGER }^{\circledR}\end{array}$ & $\begin{array}{l}\text { PLLA-PDLA-PGA } \\
85: 5: 10\end{array}$ & 8 weeks & 24-30 months \\
\hline $\begin{array}{l}\text { Inion CPS Baby } \\
\text { INION }\end{array}$ & $\begin{array}{l}\text { PLLA-PGA-TMC } \\
\% \text { not facilitated }\end{array}$ & 6-9 weeks & $1-2$ years \\
\hline $\begin{array}{l}\text { Inion CPS Adults }{ }^{\circledR} \\
\text { INION }\end{array}$ & $\begin{array}{l}\text { PLLA-PDLLA- TMC } \\
\% \text { not facilitated }\end{array}$ & 9-14 weeks & $2-4$ years \\
\hline
\end{tabular}

\section{Systems}

System $1,5 / 2,0$. Thikness $0,6 \mathrm{~mm}$ Screws 1,5, 2,0, 2,5

System $1,5 / 2,0$
System $2,0 / 2,4$
Thikness $0,6 \mathrm{~mm}$
System 1,5 y 2,0
Thikness $0,8 \mathrm{~mm}$
Single miniplat system
Screws $1,6,2,1,2,4$
Meshes $0.3-0.6-1 \mathrm{~mm}$ espesor
System 1.5 y 2.0
Thikness $0.5-1.2 \mathrm{~mm}$
Systems 1.5 y 2.0
Thikness $0.5-1.2 \mathrm{~mm}$
Systems 1.7 y 2.2
Thikness $1 \mathrm{~mm}$
CPS Baby 1,5
Thikness $0.8 \mathrm{~mm}$
CPS Adults $1.5,2.0,2.5$
Thikness $1 \mathrm{~mm}$

Time in which they conserve at least $70 \%$ of their mechanical resistance.

gún paciente ha precisado reintervención; durante las primeras 34 primeras semanas postoperatorias el maxilar tiene cierta movilidad cuando es segmentado y es más sensible a las fuerzas de tracción de los elásticos. Inicialmente, en los primeros momentos de la curva de aprendizaje, esta movilidad era preocupante pero sin embargo a largo plazo no hemos observado ningún problema de esta-
One of the most controversial aspects regarding the use of resorbable osteosynthesis is stability, as cases requiring surgical reintervention in order to stabilize the maxilla have been published. ${ }^{22}$ Clinically, it is evident that there is less fixation than with titanium and, in this respect, in segmental maxillary osteotomies the maxilla is movable, and the osteosyn- 

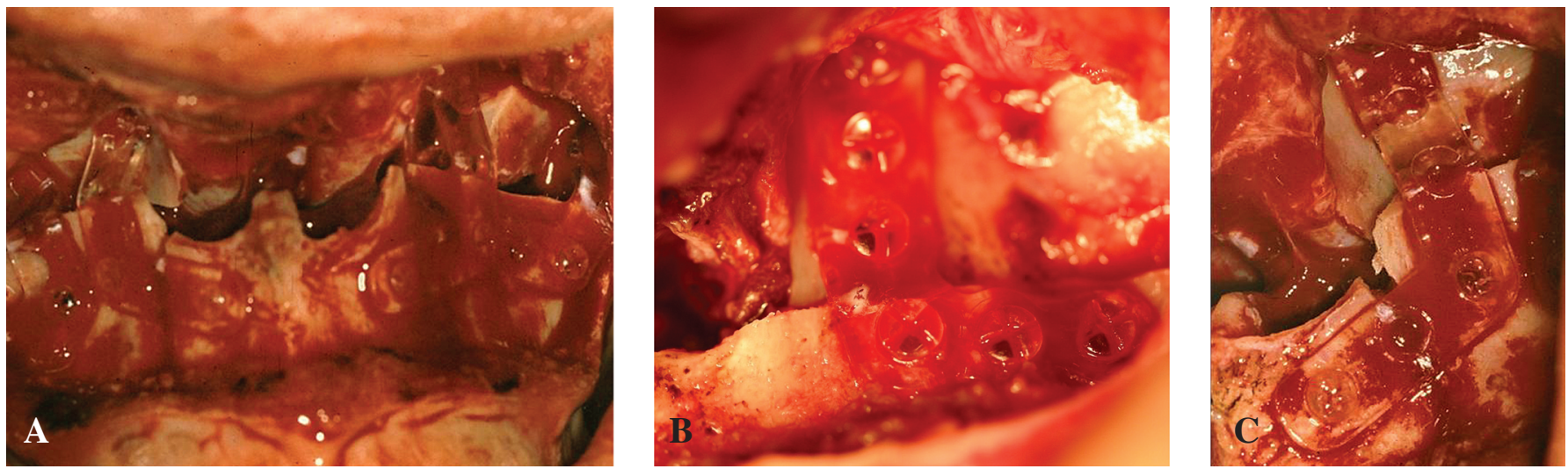

Figura 1. 1. Osteosíntesis maxilar (osteotomía Le Fort I). A. Miniplacas en Le Fort I segmentado. B. Miniplaca paranasal en Le Fort I clásico. C. Miniplaca paranasal en Le Fort I segmentado.

Figure 1. Maxillary osteosynthesis (Le Fort I osteotomy). A. Miniplates in segmental Le Fort I. B. Paranasal miniplate in classic Le Fort I. C. Paranasal miniplate in segmental Le Fort I.

bilidad. Es más, pensamos que esta menor resistencia del maxilar a las fuerzas de los elásticos, facilita en algunos casos el trabajo ortodóncico postoperatorio. Los casos más difíciles de manejar en este sentido son las expansiones maxilares, dato que ya conocíamos con la osteosíntesis con titanio. En relación con el bloqueo intermaxilar, no lo utilizamos en nuestro protocolo quirúrgico de cirugía ortognática, y tampoco ha sido necesario en ningún caso de los casos fijados con material reabsorbible.

Otras variables a comparar, además de la estabilidad, son el tiempo quirúrgico, la sencillez del procedimiento, la estancia hospitalaria, la inflamación postoperatoria y las complicaciones. Los problemas más importantes radican inicialmente en la colocación de las placas, menos manejables y cómodas que las de titanio, y que precisa un tiempo de entrenamiento. Por otra parte, en la mayor parte de los sistemas, las miniplacas precisan de calentamiento antes de su inserción en el campo operatorio. Algunos sistemas disponen de pistola, con carga de hasta 10 tornillos, que no precisan de terraja, que hace muy cómoda la inserción de los mismos y ha hecho disminuir considerablemente el tiempo quirúrgico. Los tornillos mandibulares precisan de terrajado (Fig. 4), aunque esta maniobra no enlentece la cirugía más de 2-3 minutos. Actualmente en nuestra serie el tiempo quirúrgico es similar con ambos métodos (titanio o reabsorbible) cuando se colocan 4 miniplacas; cuando

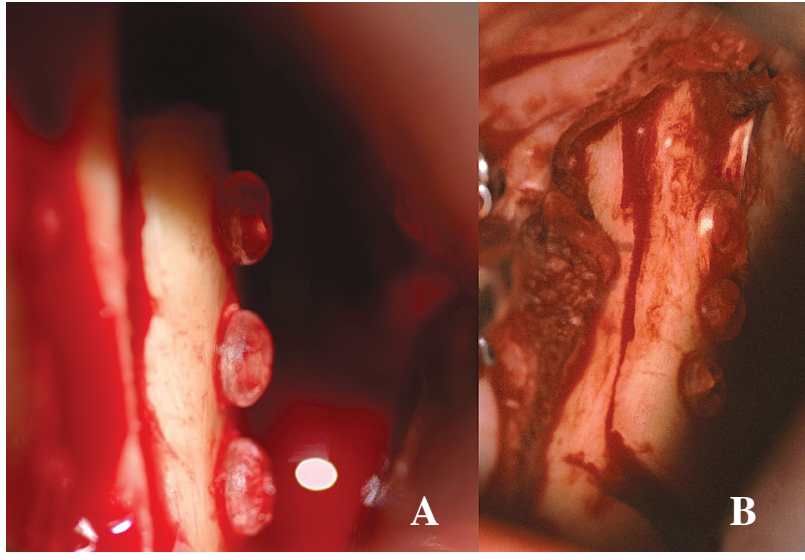

Figura 2 A y B. Osteosíntesis mandibular (osteotomía sagital) con tornillos bicorticales.

Figure $2 \mathrm{~A}$ and B. Mandibular osteosynthesis (sagittal osteotomy) with bicortical screws.

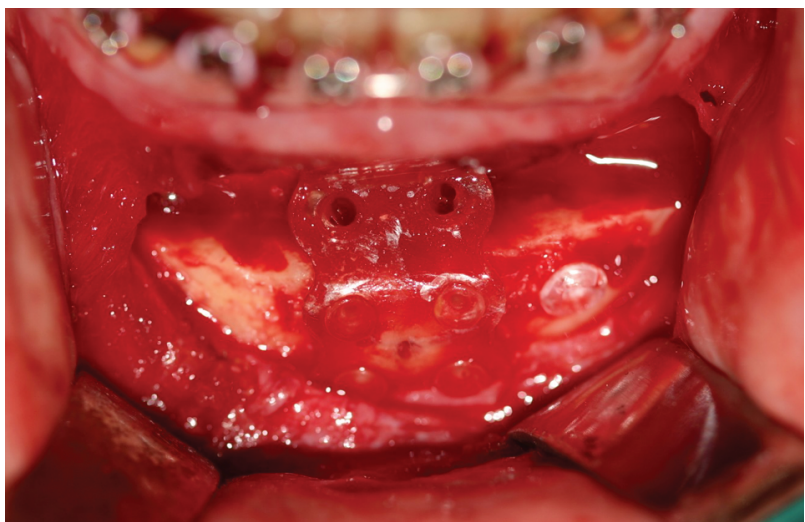

Figura 3. Osteosíntesis mentoniana (osteotomía deslizante de mentón).

Figure 3. Osteosynthesis of the chin (chin sliding osteotomy). thesis is thus semi-rigid; other than this, mobility of the segmented mandible has not been observed in any of the cases. In our series no patient needed reintervention; during the first 3-4 weeks postsurgery the maxilla has a certain amount of mobility when segmented, and it is more sensitive to the traction forces of the elastics. This movement is a worry at first during the learning curve, but in the long term, however, we have not observed any problems regarding stability. Moreover, we believe that this reduced resistance of the maxilla to the elastic forces facilitates, in some cases, postoperative orthodontic work. The cases that are most difficult to handle in this sense, are maxillary expansions, which we had already experienced with titanium osteosynthesis. With regard to intermaxillary wiring, we do not include it in our surgical protocol for orthognathic surgery, and on no occasion has it been necessary for those cases in which fixation was carried out with resorbable material.

Other variables that should be compared, in addition to stability, are surgical time, procedure simplicity, hospital 
únicamente se utilizan 2 placas preformadas de titanio (todavía no existen en los sistemas reabsorbibles), con el material reabsorbible la cirugía dura 10 o 15 minutos más. El mayor tamaño de las placas hace más engorrosa su colocación y también las hace más aparentes. En este sentido, en 2 pacientes es posible palpar las placas debajo del reborde infraorbitario, aunque no se ha precisado su extracción (Fig. 5). Actualmente cortamos el último agujero de las placas en $L$ para que no lleguen al reborde infraorbitario y comprobamos que no se palpan antes de atornillar. La inflamación postoperatoria no ha resultado diferente que en la osteosíntesis con titanio. Tampoco la estancia hospitalaria.

Entre las complicaciones, no hemos observado ningún caso de infección. Hemos observado un caso de exposición del material de osteosíntesis 9 meses después de la cirugía, en el vestíbulo maxilar, correspondiendo a un fragmento de miniplaca del segmento maxilar avanzado, que se retiró a través de una mínima incisión (Fig. 6).

En cirugía craneofacial pediátrica el único material que empleamos es el reabsorbible y los resultados por lo tanto ya no permiten comparación con el titanio (Figs. 7 y 8 ).

En trauma facial de adultos no utilizamos el material reabsorbible de forma rutinaria y no disponemos en nuestra serie de un seguimiento largo por lo que no podemos comparar la estabilidad a largo plazo. Si exceptuamos los casos de fracturas con conminución importante y fracturas muy desplazadas, donde no es aconsejable la utilización de las placas reabsorbibles, no hemos observado problemas de estabilidad a corto plazo ni tampoco complicaciones (Figs. 9-11). Sí debemos señalar que las osteosíntesis de los fragmentos en las fracturas en algunas localizaciones faciales, resultan más engorrosas.

\section{Discusión}

La utilización de placas reabsorbibles en cirugía craneofacial pediátrica es rutinaria en la actualidad, habiendo desplazado al titanio por sus efectos adversos. El material metálico no es ideal por-

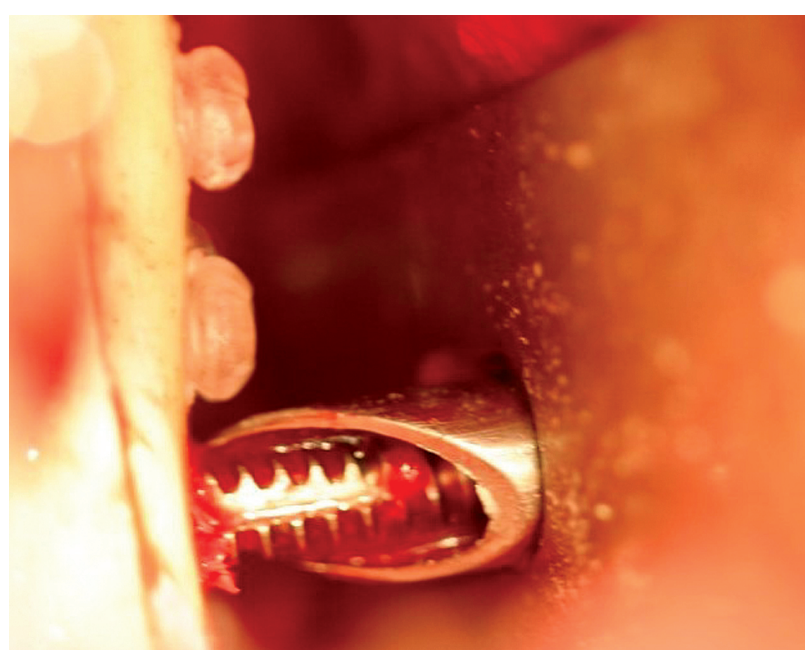

Figura 4. Terrajado de los tornillos mandibulares (osteotomía sagital).

Figure 4. Screwing mandibular screws (sagittal osteotomy).

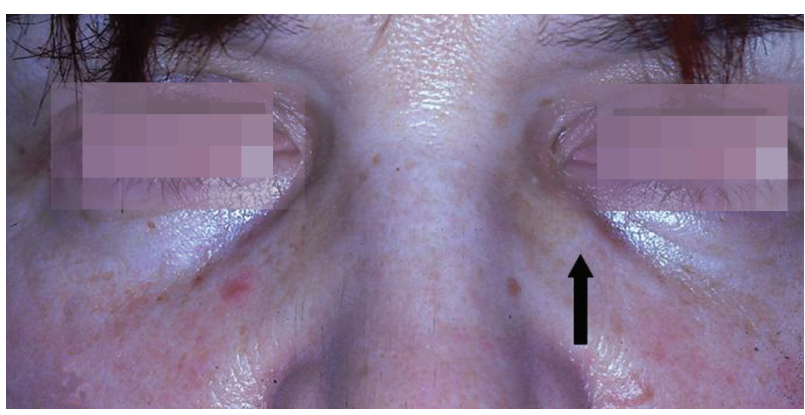

Figura 5. Miniplaca maxilar visible en la región paranasal izq. Figure 5. Visible maxillary miniplate in left paranasal region.

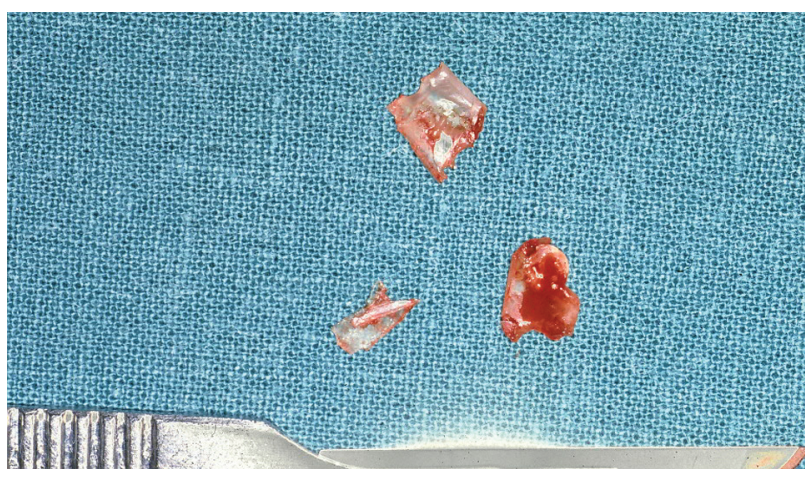

Figura 6. Fragmentos de miniplaca maxilar extraídos del vestíbulo oral.

Figure 6. Fragments of maxillary miniplate extracted form the oral cavity. stay, postoperative inflammation and complications. The most important problems arise initially on placing the plates, as these are less malleable and easy to use than those of titanium, and this requires some training. On the other hand, in the operative field, most systems require the heating of the miniplates before insertion. Some systems have a pistol that can take up to ten screws and, as a diestock is not required, insertion is very easy, meaning that operative time is reduced considerably. Mandibular screws require diestocks (Fig. 4), although this procedure does not delay the surgery more than 2-3 minutes. In our series, operative time with both methods is similar (titanium or resorbable) when 4 miniplates are placed; when only 2 preformed plates are used of titanium (in the resorbable system these do not exist) with resorbable material, the surgery take 10 to 15 minutes longer.

The larger the size of the plate, the more cumbersome placing it is, and the more obvious they are. In this sense, in two patients it was possible to feel the plate under the infraorbital rim, although extraction was not necessary (Fig. 5). We are currently cutting the last hole of the plates in an L shape so that they do not reach the infraorbital rim and we check that they are not palpable before screwing them.

Postoperative inflammation has not been any different to that experienced in osteosynthesis with titanium. Neither has hospital stay varied.

No cases of infection were observed among the complications. We observed one case of exposure of osteosynthesis material in the maxillary cavity 9 months after surgery, corresponding to a miniplate fragment from the segment of the 
que pueden provocar alteración del crecimiento de la bóveda craneal y algunos autores recomiendan retirarlos. ${ }^{23}$ Por otra parte es muy difícil su utilización en cráneos menores de 6 meses por su debilidad.

Se han documentado placas y tornillos palpables en zonas de piel fina; ocasionalmente extrusión a través de la piel; casos infrecuentes de infección secundaria a reacción a cuerpo extraño. Sin embargo, la mayor importancia se centra en la migración de las placas a través de la duramadre, en un porcentaje importante; más frecuente en la región temporal y en los casos sindrómicos. ${ }^{24}$

Por otro lado, la fijación rígida permanente en un cráneo en crecimiento puede ocasionar por sí misma la aparición de deformidades residuales. ${ }^{25}$ Numerosas publicaciones avalan el uso y buen resultado de las miniplacas reabsorbibles en este tipo de pacientes. ${ }^{26-30}$

La utilización de placas reabsorbibles en trauma craneofacial está menos documentada que en cirugía craneofacial de deformidades pero es suficiente para comprobar su utilidad. Eppley y Prevel ${ }^{31}$ publicaron en 1997 su experiencia en fracturas del tercio medio facial con el uso de Lactosorb en 30 pacientes. Con un seguimiento mayor de un año, observó una cicatrización adecuada y sin reacciones adversas, aunque el autor recomienda no usarla en fracturas de frag-

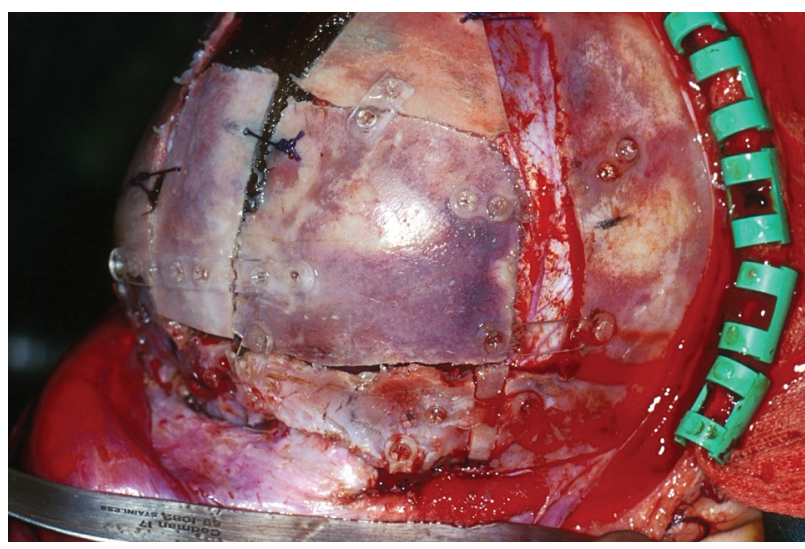

Figura 7. Osteosíntesis craneofacial en craneoplastia por plagiocefalia.

Figure 7. Craniofacial osteosynthesis in cranioplasty due to plagiocephaly.

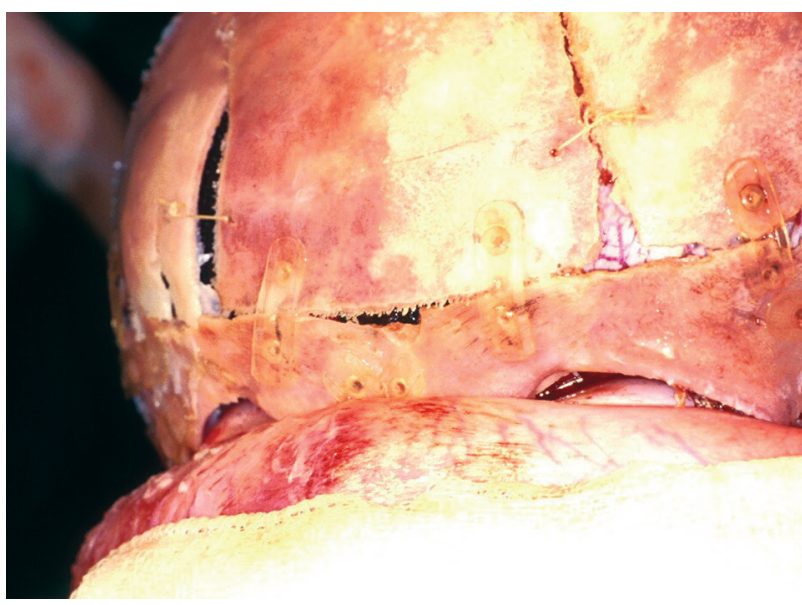

Figura 8. Osteosíntesis craneofacial en craneoplastia por trigonocefalia.

Figure 8. Craniofacial osteosynthesis in cranioplasty due to trigonocephaly. mentos pequeños y finos. Resultados

similares fueron publicados por Enislidis y $\operatorname{cols}^{32}$ en una serie de 27 fracturas maxilomalares.

Ylikontiola y cols ${ }^{33}$ han utilizado placas reabsorbibles para la osteosíntesis de fracturas parasinfisarias mandibulares de 10 adultos, con buenos resultados (un paciente sufrió exposición intraoral de una placa, que precisó su extirpación parcial). Estos autores recomiendan buena cobertura de tejidos blandos para evitar la exposición de las placas. Otros autores ${ }^{34}$ también han publicado buenos resultados en fracturas mandibulares.

Tams y cols, 35 en un estudio experimental, han comprobado que las fracturas de ángulo mandibular pueden tratarse de forma eficaz con 2 placas reabsorbibles colocadas sobre la línea oblicua externa y el tercio medio vestibular de la mandíbula, respectivamente.

Hoffmann y cols ${ }^{36}$ utilizaron placas PDLLA (Resorb X) en 22 pacientes tratados de trauma craneofacial, osteotomía Le Fort I y síndromes craneofaciales, no habiendo observado complicaciones en la cicatrización (clínica y radiológica). maxilla that had been advanced, which was removed using a mini incision (Fig. 6).

In pediatric craniofacial surgery the only material that is used is resorbable, and the results therefore cannot be compared with titanium (Figs. 7 and 8).

In adult facial trauma we do not use resorbable material in a routine way and, as we do not have a long-term follow-up in our series, we cannot compare stability in the long term. If we make an exception of fracture cases having significant comminution and fractures that are severely displaced where the use of resorbable plates is not advised, we have not observed problems of stability in the short term nor complications (Figs. 9-11). We should, however, point out that osteosynthesis of fragment fractures in some facial localizations, result more cumbersome.

\section{Discussion}

The use of resorbable plates in pediatric craniofacial surgery is currently routine, as titanium has been displaced because of its adverse effects. Metallic material is not ideal because it can produce growth alterations in the cranial vault and some authors recommend removing them. ${ }^{23}$ On the other hand their use in the skulls of [infants] under the age of six months is very difficult because of weakness.

Documented cases include; palpable plates and screws in areas of fine skin; occasional extrusion through the skin; infrequent cases of secondary infection because of foreign body reaction. However, of most concern is the significant percentage of plate migration through the dura mater, which is more frequent in the temporal region and in syndromic cases. ${ }^{24}$

On the other hand, permanent rigid fixation in a growing cranium can lead in itself to the appearance of residual deformities. ${ }^{25}$ Numerous publications support the use and positive results of resorbable miniplates in this type of patient. ${ }^{26}$ 30 


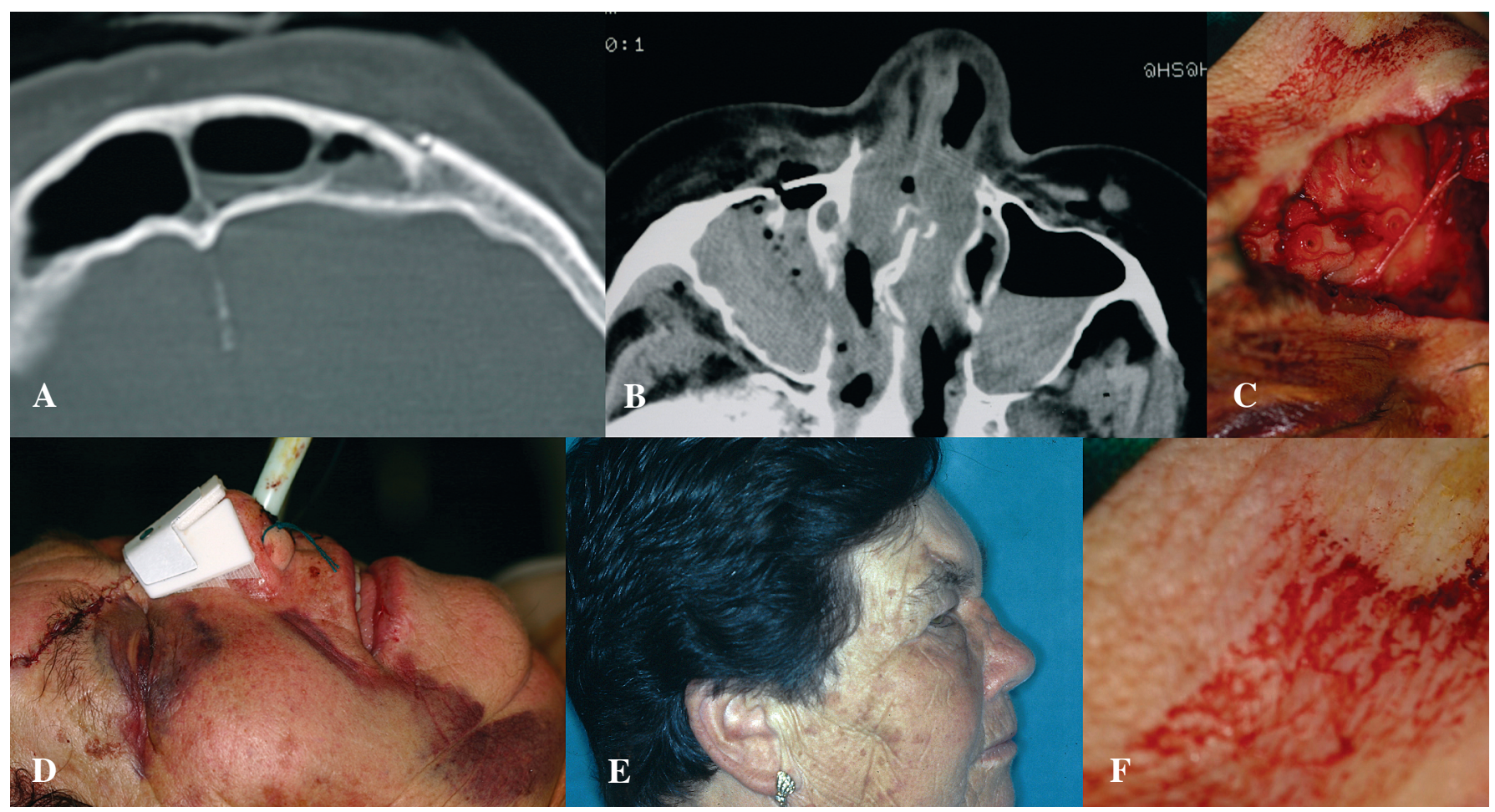

Figura 9. Osteosíntesis en paciente con fractura frontal y maxilar. A. Imagen radiológica de fractura frontal. B. Imagen radiológica de fractura maxilar. C. Osteosíntesis de fractura frontal. D. Postoperatorio inmediato en quirófano (osteosíntesis frontal y maxilar sin bloqueo intermaxilar). E. Perfil facial (1 mes postoperatorio). F. Oclusión dentaria (1 mes postoperatorio).

Figure 9. Osteosynthesis in a patient with a frontal and maxillary fracture. A. Radiologic image of frontal fracture. B. Radiological image of maxillary fracture. C. Osteosynthesis of frontal fracture. D. Immediately after surgery in operating room (frontal and maxillary osteosynthesis without maxillary wiring). E. Facial profile (1 month postop.). F. Dental occlusion (1 month postop.).

Suuronen y cols, ${ }^{1}$ en un estudio retrospectivo de más de 200 pacientes tratados con fijación reabsorbible en varias aplicaciones de cirugía craneomaxilofacial a lo largo de 7 años, sostienen que las placas reabsorbibles pueden utilizarse de rutina en la osteosíntesis maxilofacial.

La otra gran aplicación de las placas reabsorbibles es la cirugía ortognática. En este campo la literatura se incrementa constantemente con numerosos artículos documentando su uso. Haers y cols, 37 publicaron en 1998 el primer caso de cirugía bimaxilar y mentoplastia simultáneas fijadas exclusivamente con material reabsorbible. Turvey y cols, 38 han publicado su experiencia en 70 pacientes de cirugía ortognática bimaxilar con seguimiento a corto plazo (6-24 meses). Tres pacientes tuvieron problemas con la pérdida de tornillos pero la estabilidad y la oclusión fueron adecuadas en todos los pacientes.

Norholt y cols, 39 han comparado el uso de placas reabsorbibles Lactosorb ${ }^{\circledR}$

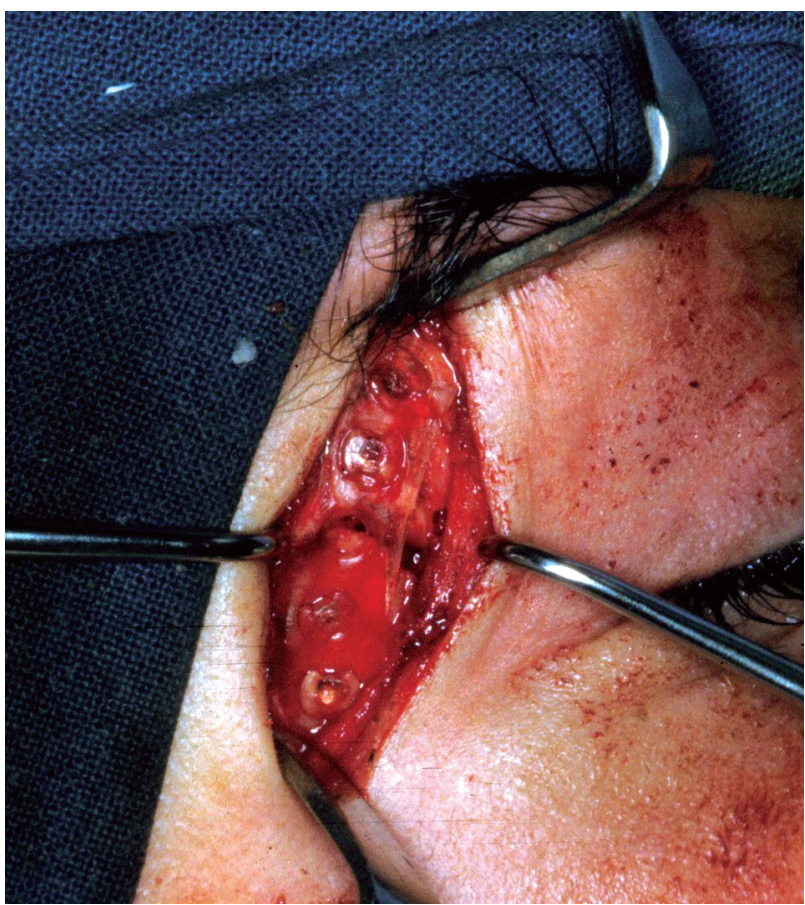

Figura 10. Osteosíntesis del reborde orbitario externo en fractura malar derecha.

Figure 10. Osteosynthesis of external orbital rim in right malar fracture.
In craniofacial trauma the use of resorbable plates has been less documented than in craniofacial surgery for deformity, but it is sufficient to justify its use. Eppley and Prevel ${ }^{31}$ published in 1997 their experience in midface fractures with the use of Lactosorb in 30 patients. The follow-up period was of more than a year, and adequate healing with no adverse reactions was observed, although the authors did not recommend their use in small or fine fracture fragments. Similar results were published by Enislidis and cols. 32 in a series of 27 maxillomalar fractures.

Ylikontiola and cols ${ }^{33}$ have used resorbable plates for the osteosynthesis of parasymphyseal fractures in 10 
y de titanio en la osteosíntesis de Le Fort $\mathrm{I}$, en un estudio randomizado y prospectivo sobre 60 pacientes, en relación con la estabilidad y morbilidad. Estos autores, 39 han observado un cambio vertical medio de 0,6 $\mathrm{mm}$ a las 6 semanas postop $^{\circledR}$ en el grupo reabsorbible (cambio estadísticamente significativo, medido con implantes metálicos colocados en el hueso), no encontrando cambios significativos en el grupo de titanio. Este cambio no fue clínicamente aparente y no se observó en los siguientes controles radiológicos, habiendo completado satisfactoriamente la consolidación ósea

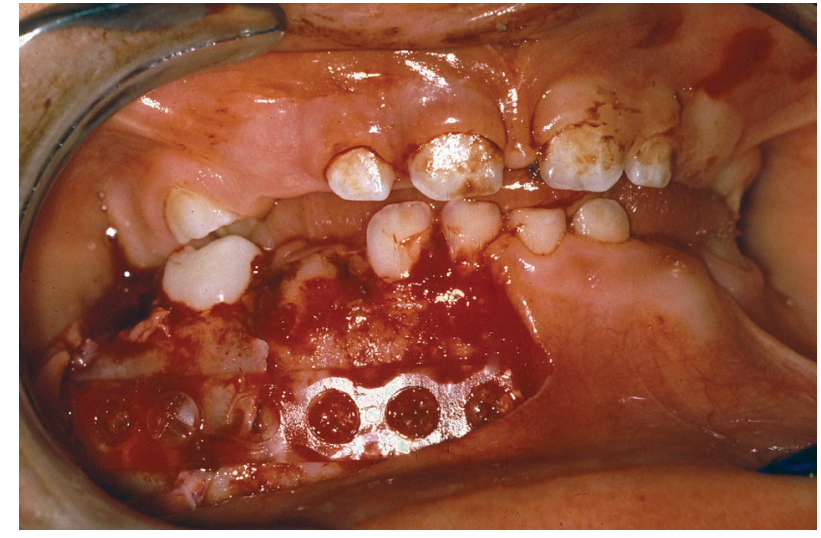

Figura 11. Osteosíntesis de fractura parasinfisaria mandibular. Figure 11. Osteosynthesis of mandibular parasymphyseal fracture. adults, with good results (one patient suffered intraoral exposure of a plate, which required partial extirpation). These authors recommend adequate soft tissue cover in order to avoid plate exposure. Other authors ${ }^{34}$ have also published good results for mandibular fractures.

Tams and cols, 35 in an experimental study, confirmed that mandibular angle fractures could be treated efficiently with 2 resorbable plates placed on the external infección y dehiscencia de herida con las placas reabsorbibles, mientras que en el grupo de titanio se palpaban más frecuentemente las placas 6-12 meses después y 3 casos requirieron su retirada.

Matthews y cols, 12 han estudiado la estabilidad de los tornillos SR-PLLA reabsorbibles en la osteosíntesis de la osteotomía sagital mandibular de avance en 11 pacientes, comparándola con una cohorte de 11 pacientes sometidos a la misma osteotomía fijada con titanio, y no han encontrado diferencias significativas entre ambos grupos al comparar la estabilidad cefalométrica con seguimiento de un año. Otros estudios sobre osteotomías Le Fort I y osteotomía sagital mandibular han mostrado la ausencia de complicaciones. ${ }^{40-43}$

Ferretti y Reyneke, ${ }^{44}$ han publicado un estudio prospectivo comparativo sobre 40 pacientes con clase II sometidos a osteotomía sagital mandibular, en el que han comparado la estabilidad a largo plazo y las complicaciones entre la fijación con tornillos de titanio y tornillos de $\mathrm{P}(\mathrm{L} / \mathrm{DL}) \mathrm{LA}$ 82:18, y no han encontrado diferencias significativas entre ambos grupos.

El grupo de Helsinki ha mostrado su experiencia en cirugía ortognática durante 8 años, con seguimientos de más de 5 años, con resultados excelentes.1,14 Recientemente han publicado su experiencia en cirugía ortognática en un periodo de 10 años (19912001 ) en un estudio retrospectivo sobre 163 pacientes y 329 osteotomías. ${ }^{45}$ La aceptación de los pacientes ha sido excelente y la incidencia de complicaciones observadas fue muy baja, sin afectar el resultado final en ningún caso: $8,6 \%$ de complicaciones menores, 0,6\% (un caso) de infección y 1,8\% (3 casos) de mordida abierta postoperatoria, que ocurrió con los dispositivos antiguos en la primera fase del estudio.

Fuente del Campo, 46 ha publicado recientemente en un estudio multicéntrico, su experiencia en osteosíntesis maxilofacial con material reabsorbible (SR-PLLA) en 208 casos, de los cuales 142 correspondían a cirugía ortognática, con un seguimiento máximo de 8 años. Este autor ha observado una tasa de complicaciones del 7,9\%: 2 casos de inestabilidad maxilar por mala técnica, 6 casos de granuloma, 4 casos de exposición de placa y otros 4 de desplazamiento de la misma, siendo la mayor parte de estas complicaciones atribuidas a la técnica y no al material empleado. oblique ridge and half way up the height of the mandible respectively.

Hoffmann and cols ${ }^{36}$ used the PDLLA (Resorb X) plates in 22 patients treated for craniofacial trauma, Le Fort 1 osteotomy and craniofacial syndromes, with no complications being observed in healing (neither clinically nor radiologically). Suuronen and cols, in a retrospective study of more than 200 patients treated with resorbable fixation in various applications of craniomaxillofacial surgery over 7 years, maintain that resorbable plates can be used routinely in maxillofacial osteosynthesis.

The other considerable application of resorbable plates is in orthognathic surgery. In this field the literature increases constantly, with numerous documented articles as to their application. Haers and cols. ${ }^{37}$ published in 1998 the first case of simultaneous bimaxillary surgery and mentoplasty fixed exclusively with resorbable material. Turvey and cols. 38 published their experience with 70 patients in orthognathic bimaxillary surgery with a short-term follow-up (6-24 months). Three patients had problems with screw loss, but stability and occlusion were adequate in all patients.

Norholt and cols. ${ }^{39}$ have compared the use of Lactosorb resorbable plates and titanium plates in Le Fort 1 osteosynthesis, in a randomized prospective study of 60 patients, in relation with stability and morbidity. These authors ${ }^{39}$ observed an average postoperative vertical change of $0.6 \mathrm{~mm}$ at 6 weeks in the resorbable group (a significant statistical change carried out with metallic implants placed in the bone), but they did not find significant changes in the titanium group. There was no clinically apparent change, nor did any appear in the following radiological evaluations, bone consolidation having taken place satisfactorily in all patients. There were 2 cases of wound infection and dehiscence with the resorbable plates while, in the titanium group, the plates were more frequently palpated 6-12 months later, and 3 cases required removal.

Matthew and cols12 studied the stability of the SR-PLLA resorbable screws in osteosynthesis for sagittal split mandibular advancement osteotomies in 11 patients, compared with a cohort of 11 patients submitted to the same osteotomies 
Parece claro que en cirugía ortognática el material reabsorbible es una alternativa absolutamente válida al titanio.

\section{Ventajas y desventajas de la osteosíntesis reabsorbible}

La literatura revisada muestra en general que las placas reabsorbibles son una alternativa válida al titanio en la mayor parte de las osteosíntesis craneomaxilofaciales. Se publican mayores índices de complicaciones en las series pequeñas, que suelen corresponder a la primera fase de utilización de estos materiales. Algunos problemas permanecen sin resolver, como la biodegradación prolongada. ${ }^{47}$ Otro problema es la palpabilidad de la placas. Gerlach, ${ }^{48}$ utilizando placas reabsorbibles en el tratamiento de fracturas malares, observó que se palpaban después de 2 años a través de la piel. También observó que de 15 pacientes tratados, 2 presentaron una reacción inflamatoria no infecciosa a los 30 meses. Por otra parte Bergsma y cols, ${ }^{15}$ observaron en su serie que todos los pacientes desarrollaron una reacción a cuerpo extraño en la zona operatoria 3 años después. Se encontraron fragmentos de LPLA durante la exploración quirúrgica hasta 5,7 años más tarde.

Hay que señalar que estas publicaciones corresponden a las fases iniciales de utilización de la osteosíntesis reabsorbible.

El material reabsorbible ideal debe soportar los fragmentos óseos durante el periodo de curación y además reabsorberse en su totalidad cuando éste se ha completado, sin que los metabolitos resultantes causen ninguna alteración local o sistémica. ${ }^{12}$ Estas características proporcionan indudables ventajas sobre todo porque no precisan su extracción. Se ha publicado un $11,1 \%$ de pacientes que precisaron la extracción de las placas de titanio en cirugía ortognática, ${ }^{49} \mathrm{y}$ del $11,5 \%$ en fracturas mandibulares. ${ }^{50}$ Por otra parte es particularmente ventajoso en países donde habitualmente se retira postoperatoriamente el material de osteosíntesis, lo que conlleva anestesia general, morbilidad y coste económico. También se evitan las interferencias que el titanio puede producir con procedimientos radiológicos, ${ }^{2}$ y la sensibilidad térmica. ${ }^{51}$

\section{Análisis de las desventajas}

\section{de la osteosíntesis con material reabsorbible:}

- Propiedades físicas. Uno de los inconvenientes es el grosor de las placas. Para la misma resistencia se necesita mayor grosor de las placas reabsorbibles. Esto es un inconveniente en algunas localizaciones y situaciones específicas. Otro problema es la difícil aplicación en fracturas conminutas y huesos muy finos. En estas condiciones es difícil adaptar estas placas por lo que puede ser una contraindicación. Si se doblan demasiadas veces, algunos autores, ${ }^{52}$ señalan que el procedimiento de calentado puede hacer perder sus propiedades mecánicas aunque esto también supone un problema con el titanio.

- Curva de aprendizaje. El manejo y adaptación de estas placas es más engorroso que al que estamos habituados con el titanio, por lo que inicialmente el tiempo quirúrgico es mayor. Esto es debido al proceso de calentado y la necesidad de terrajado del orificio que requiere la mayoría de los sistemas; el desarrollo de pistolas fixed with titanium. They did not find significant differences between both groups on comparing cephalometric stability during a follow-up period of one year. Other studies of Le Fort 1 osteotomies and mandibular sagittal osteotomies have shown the absence of complications. $40-43$

Ferretti and Reyneke ${ }^{44}$ have published a prospective comparative study of 40 patients with class II malocclusion who underwent sagittal split osteotomies of the mandible, in which long-term stability was compared with the complications [arising] from the fixation with titanium screws and with $P(L / D L) L A$ 82:18 screws, with no significant differences being found between both groups.

The Helsinki group demonstrated their 8-year experience in orthognathic surgery together with a follow-up of more than 5 years, with excellent results. 1,14 Recently they published their experience in orthognathic surgery during a 10year period (1991-2001) in a retrospective study of 163 patients and 329 osteotomies. ${ }^{45}$ Patient acceptance was excellent and the incidence of complications observed was minor, with no cases influencing the final result: $8.6 \%$ with minor complications, $0.6 \%$ (one case) of infection and $1.8 \%$ (3 cases) of postoperative open bite, which occurred with the older devices in the first phase of the study.

Fuente del $\mathrm{Campo}^{46}$ has recently published his experiences in a multicentric study of maxillofacial osteosynthesis with resorbable material (SR-PLLA) in 208 cases, of which 142 corresponded to orthognathic surgery, with a maximum following of 8 years. This author 46 observed a complication rate of 7.9\%: 2 cases of maxillary instability because of bad technique, 6 cases of granuloma, 4 cases of plate exposure and another 4 of displacement. Most of these complications were attributed to technique and not to the material used.

It seems clear that, for orthognathic surgery, resorbable material is an absolutely valid alternative to titanium.

\section{Advantages and disadvantages to resorbable osteosynthesis}

The literature revised shows that, in general, resorbable plates are a valid alternative to titanium in most craniomaxillofacial osteosynthesis. Larger rates of complications are published in small series that tend to correspond to the first application phase of these materials. Some problems remain unresolved, such as prolonged biodegradation. ${ }^{47}$ Another problem concerns the plates being palpable. Ger$l^{l a c h}{ }^{48}$, using resorbable plates for the treatment of malar fractures, observed that these could be palpated through the skin after two years. He also observed that of 15 patients treated, two presented a non-infectious inflammatory reaction after 30 months. On the other hand, Bergsma and cols 15 observed a series in which all patients developed foreign body reaction in the operated area three years later. Fragments of LPLA fragments were found during the surgical examination as much as 5.7 years later. 
para introducir los tornillos en el agujero sin necesidad de terrajado ha posibilitado disminuir el tiempo quirúrgico sin perjuicio de sus propiedades mecánicas. Esto ha sido demostrado tanto en estudios experimentales, ${ }^{53}$ como clínicos, $^{54}$. Sin embargo, es difícil su uso en huesos muy finos por la posibilidad de fractura. ${ }^{55}$

Esto requiere una curva de entrenamiento inicial para familiarizarse con el material, ${ }^{45}$ aunque hoy por hoy la calidad de manejo es inferior al titanio; sin embargo, esto no compromete el resultado final.

- Manejo en cirugía ortognática. El atornillado de la osteotomía sagital mandibular es idéntico con titanio o reabsorbible, únicamente se requieren unos segundos más para el terrajado de los orificios. En el maxilar, la movilidad inicial, durante 4-5 semanas, puede parecer preocupante, sobre todo en los segmentados, pero realmente no lo es y no hay problema de estabilidad al cabo de ese periodo. ${ }^{45}$ Otro aspecto que entraña cierta dificultad es la colocación de las miniplacas en la premaxila en la osteotomía de los Le Fort segmentados. Actualmente se está trabajando en el desarrollo de placas preformadas reabsorbibles para los avances maxilares (tipo Lindorf o Prebent); esto hará la colocación de la osteosíntesis maxilar tan sencilla como el titanio. Un aspecto ya mencionado es la palpación de las placas en el reborde infraorbitario, que no es un problema actualmente.

- No visualización de los tornillos en las placas radiográficas. Esto ocasionalmente puede dificultar actitudes diagnósticas cuando hay problemas de consolidación, etc. ${ }^{45}$

- Se necesita una cobertura adecuada de partes blandas para que no haya exposición de las placas ya que el proceso de degradación de las mismas se altera. En estos casos es necesario retirarla después del periodo de consolidación ósea.

- Versatilidad de las miniplacas. Algunas compañías solo disponen de un único sistema, no válido para todas las osteosíntesis. Generalmente estos sistemas no están indicados en osteosíntesis mandibular o situaciones que requieren mayor resistencia. Así, Dolanmaz y cols, ${ }^{56}$ aconsejan la fijación intermaxilar en el postoperatorio inmediato tras comparar experimentalmente en ovejas la estabilidad de las placas reabsorbibles PLLA-PGA 82:18 y de titanio en la osteosíntesis de la osteotomía sagital mandibular con un avance de $5 \mathrm{~mm}$.

- Coste. Actualmente el coste de la osteosíntesis reabsorbible es 23 veces superior a la osteosíntesis con titanio. Sin embargo, si tenemos en cuenta el coste de la extracción del titanio, en un porcentaje no despreciable, y de que en algunos países es rutinaria su retirada, es evidente que es más barato que el titanio. Por otra parte en algunos países, y próximamente en el resto de la CEE, el estocaje del material de osteosíntesis de titanio será igual al reabsorbible, es decir, envasado en paquetes de una o varias unidades, no en un embalaje común como hasta ahora), lo que hará encarecer el producto. También es de esperar que con la mayor popularización del material reabsorbible el precio tienda a la baja.

\section{Conclusiones}

La utilización de placas y tornillos reabsorbibles en la osteosíntesis craneomaxilofacial es cada día más frecuente. La literatura
It should be stressed that these publications correspond to the initial phases in which resorbable osteosynthesis was used. The ideal resorbable material should be able to support bone fragments during the healing period, and it should be able to reabsorb itself completely after this without the resulting metabolites causing any local or systemic alterations. ${ }^{12}$ These characteristics provide undoubted advantages, particularly as they do not have to be extracted. It has been published that $11.1 \%$ of patients required the extraction of titanium plates in orthognathic surgery and $11.5 \%$ in mandibular fractures.50 On the other hand, it is of particular advantage in countries in which osteosynthesis material is removed postoperatively, which entails general anesthesia, morbidity and economic cost. The interferences that titanium can produce regarding radiological procedures ${ }^{2}$ and thermal sensitivity are avoided ${ }^{51}$.

Analysis of the disadvantages

of osteosynthesis with resorbable material

- Physical properties. One of the inconveniences is the thickness of the plates. For the same resistance a greater thickness of resorbable plate is needed. This is an inconvenience in some localizations and specific situations. Another problem is the difficult application in comminuted fractures and very fine bones. In these conditions, adapting these plates is very difficult, which could be a contraindication. If they are bent too many times, some authors 52 indicate that the heating procedure can make them lose their mechanical properties although this also poses a problem with titanium.

- Learning curve. Handling and adapting these plates is more cumbersome than what we are used to with titanium, so initially operative time is longer. This is due to the heating process and the need for adjustments to the orifice that most systems require; the development of shooters for introducing the screws into the holes without the need for a diestock has meant that operative time is reduced without prejudicing the mechanical properties. This has been demonstrated in experimental ${ }^{3}$ as well as clinical$^{54}$ studies. However, its use in fine bones is difficult because of the possibility of fracturing them. ${ }^{55}$

This requires an initial training curve for familiarization with the material, ${ }^{45}$ although the ease of handling is still today lower than with titanium; however, this does not compromise the end result.

- Handling in orthognathic surgery. For a sagittal mandibular osteotomy the screws are inserted in the same way in both the titanium and resorbable systems, only a few more seconds are required for adjustments to the orifices. In the maxilla, the initial mobility during 4-5 weeks may be of concern, especially in segmental osteotomies, but in actual fact it is not, and there is no problem regarding stability at the end of this period. ${ }^{45}$ Another aspect entailing some difficulty is the placing of miniplates in the pre- 
demuestra que es una alternativa válida a la osteosíntesis con titanio en la mayoría de las situaciones clínicas. Actualmente, presentan todavía algunas desventajas en relación con el titanio, como la mayor incomodidad de uso y el coste económico. Si excluimos las fracturas con fragmentos finos y conminutos y algunas situaciones específicas, el material reabsorbible puede sustituir al titanio en la osteosíntesis craneomaxilofacial actual. Únicamente es necesaria experiencia para superar la curva de aprendizaje inicial que hace su utilización más incómoda.

Por otra parte, son necesarios estudios para comparar entre sí los distintos sistemas reabsorbibles ya que la composición, y por lo tanto sus características, varía de unos a otros.

\section{Bibliografía}

1. Suuronen R, Kallela I, Lindqvist C. Bioabsorbable plates and screws: Current state of the art in facial fracture repair. / Craniomaxillofac Trauma 2000;6:19-27.

2. Sullivan PK, Smith JF, Rozzelle AA. Cranio-orbital reconstruction: safety and image quality of metallic implants on CT and MRI scanning. Plast Reconstr Surg 1994; 94:589-96.

3. Scher N, Poe D, Kuchnir F, y cols. Radiotherapy of the resected mandible following stainless steel plate fixation. Laryngoscope 1988;98:561-63.

4. Schliephake $H$, LehmannH, Kunz U, Schmelzeisen R. Ultrastructural findings in soft tissues adjacent to titanium plates used in jaw fracture treatment. Int J Oral Maxillofac Surg 1993;22:20-5.

5. Kulkarni RK, Pani KC, Neuman C, Leonard F. Polylactic acid for surgical implants. Arch Surg 1966;93:839-43.

6. Cutright DE, Hunsuck EE, Beasley JD. Fracture reduction using a biodegradable material, polylactic acid. J Oral Surg 1971;6:393-7.

7. Gerlach KL, Eitenmüller J. In vivo evaluation of 8 different polymers for use as osteosythesis material in maxillofacial surgery. En Pizzoferrato A, Marchetti PG, Ravagliori A, Lee ACJ, eds. Biomaterials and Clinical Applications. Amsterdam: Elsevier Science Publisher BV; 1987;439-45.

8. Gerlach KL, Krause HR, Eitenmüller J. Use of absorbable osteosynthesis material for mandibular fracture treatment of dogs. En Pizzoferrato A, Marchetti PG, Ravagliori A, Lee AC), eds. Biomaterials and Clinical Applications. Amsterdam: Elsevier Science Publisher BV 1987;459-464.

9. Bos RRM. Poly-L-lactide osteosynthesis. Development of bioresorbable bone plates and screws. Thesis. The Netherlands: University of Groningen 1989.

10. Suuronen R, Laine $P$, Pohjonen $T$, Lindqvist $C$. Sagital ramus osteotomies fixed with biodegradable screws. A preliminary report. J Oral Maxillofac Surg 1994; 52:715-20.

11. Eppley BL, Reilly M. Degradation characteristics of PLLA-PGA bone fixation devices. J Craniofac Surg 1997;8:116-20.

12. Matthews NS, Khambay BS, Ayoub AF, Koppel D, Wood G. Preliminary assessment of skeletal stability after sagital split mandibular advancement using a bioresorbable fixation system. Br J Oral Maxillofac Surg 2003;41:179-84.

13. Katz AR, Mukherjee PD, Kaganov AL, Gordon S: A new synthetic monofilament absorbable suture made from polytrimethylene carbonate. Surg Gynecol Obstet 1995;161:213-22.

14. Suuronen R, Haers PE, Lindqvist C, Sailer HF. Update in bioresorbable plates in maxillofacial surgery. Facial Plast Surg 1999;15:61-72.

15. Bergsma JE, de Bruijn WC, Rozema FR, Bos RRM, Boering G. Late degradation tissue response to poly(L-lactide) bone plates and screws. Biomaterials 1995;16: 25-31. maxilla for segmental Le Fort osteotomies. Currently the development of resorbable pre-formed plates is being worked on for (Lindorf or Prebent type) maxilla advancement; this will make placing maxillary osteosynthesis as simple as titanium. One aspect that we have already mentioned is the palpation of the plates in the infraorbital rim, which is not currently a problem.

- Non-visualization of screws in the radiographic film. This can sometimes make diagnosis difficult when there are consolidation problems, etc. 45

- Adequate protection is needed of soft tissue so that there is no plate exposure, as the degradation process can be altered. In these cases their removal after the consolidation period is necessary.

- Versatility of miniplates. Some companies only dispose of a single system that is not valid for all osteotomies. Generally, these systems are not indicated for mandibular osteosynthesis or for situations requiring greater resistance. Thus. Dolanmaz and cols ${ }^{56}$ recommend intermaxillary wiring in the immediate postoperative period, following an experimental comparison in sheep the stability of resorbable plates PLLA-PGA 82:18 with titanium in the osteosynthesis of the sagittal osteotomies of the mandible, with an advance of $5 \mathrm{~mm}$.

- Cost. Currently the cost of resorbable osteosynthesis is 23 times higher that titanium osteosynthesis. However, if we bear in mind the cost of extracting the titanium, which is a far from negligible percentage, and that in some countries removal is routine, it is evidently cheaper than titanium. Moreover, in some countries, and soon in the rest of the EEC, the supply of titanium osteosynthesis material will be the same as resorbable material. That is to say, they will be packaged in one or several units, (and not in a general package) which will make the product more expensive. It is to be hoped that, with the widespread use of resorbable material, the price will fall.

\section{Conclusions}

The use of resorbable plates and screws in craniofacial osteosynthesis is more frequent every day. The literature has demonstrated that it is a valid alternative to titanium osteosynthesis in most clinical situations. There are still some disadvantages compared with titanium, such as more cumbersome handling and the economic cost. If we exclude fine fracture fragments and comminuted fractures, and some specific situations, resorbable material can substitute titanium in current craniomaxillofacial osteosynthesis. Experience is the only thing needed in order to surmount the initial learning curve that makes its use more cumbersome.

Moreover, studies are needed in order to compare the different resorbable systems as the compositions, and as a result their characteristics, vary from one to another. 
16. Partio EK, Böstman O, Hirvensalo E, y cols. Self-reinforced absorbable screws in the fixation of displaced ankle fractures: A prospective clinical study of 152 patients. J Orthop Trauma 1992;6:209-15.

17. Weiler A, Helling HJ, Kirch U, y cols. Foreign-body reaction and the course of osteolysis after polyglycolide implants for fracture fixation: Experimental study in sheep. J Bone Joint Surg (Br) 1996;78:369-76.

18. Törmälä P. Biodegradable self-reinforced composite materials; manufacturing structure and mechanical properties. Clin Mater 1992;10:2934.

19. Serlo W, Kaarela OI, Peltoniemi HH, Merikanto J, Ashammakhi NA, Lassila K, Pohjonen T, Törmälä P, Waris TH. Use of self-reinforced polylactide osteosynthesis devices in craniofacial surgery: a log-term followup study. Scand J Plast Reconstr Hand Surg 2001;35:285-92.

20. Suuronen R, Laine P, Sarkiala E, Pohjonen T, Lindqvist C. Sagittal split osteotomy fixed with biodegradable, self-reinforced poly-L-lactide screws. Int J Oral Maxillofac Surg 1992;21:303-8.

21. Peltoniemi $H$, Ashammakhi N, Kontio R, Waris T, Salo A, Lindqvist $C$, Grätz K, Suuronen R. The use of bioabsorbable osteofixation devices in craniomaxillofacial surgery. Oral Surg Oral Med Oral Pathol Oral Radiol Endod 2002;94:5-14.

22. Chamorro Pons M, Cebrián Carretero JL, Martín Pérez M, Montesdeoca García N, Muñoz Caro JM, Arias Gallo J, Burgueño García M, Martorell Martinez V. Osteosíntesis reabsorbible en cirugía ortognática. Utilización del sistema PolimaxR en la fijación del maxilar superior. Rev Esp Cir Oral Maxilofac 2003;25:152-7.

23. Mühlbauer W, Anderl H, Ramatschi P y cols. Radical treatment of craniofacial anomalies in infancy and the use of miniplates in craniofacial surgery. Clin Plast Surg 1987; 14:101-11.

24. Fearon JA, Munro IR, Bruce DA. Observations on the use of rigid fixation for craniofacial deformities in infants and young children. Plast Reconstr Surg 1995;95: 634-7.

25. Posnick JC, Yaremchuck MJ. The effects of nonabsorbable internal fixation devices placed on and within a child's cranial vault: brain function, morbidity, and growth restriction. Editorial. Plast Reconstr Surg 1995;96:966-8.

26. Goldstein JA, Quereshy FA, Cohen AR. Early experience with biodegradable fixation for congenital pediatric craniofacial surgery. / Craniofac Surg 1997;8:110-5.

27. Habal MB. Editorial: A specialist's view of the new technology: The absorbable plating system. J Craniofac Surg 1997;8:83.

28. Habal MB. Absorbable, invisible, and flexible plating system for the craniofacial skeleton. J Craniofac Surg 1997;8:121-6.

29. Pensler JM. Role of resorbable plates and screws in craniofacial surgery. J Craniofac Surg 1997;8:129-34.

30. Serlo W, Ashammakhi N, Törmälä P, Waris TH. A new technique for correction of trigonocephaly in an infant: application of an absorbable endocranial plate. Child's Nerv Syst 2000; 16: 595-7.

31. Eppley BL, Prevel CD. Nonmetalic fixation in traumatic midfacial fractures. J Craniofac Surg 1997;8:103-9.

32. Enislidis G, Pichorner S, Kainberger F, Ewers R. Fixation of zigomatic fractures with a new biodegradable copolymer osteosynthesis system. Preliminary results. Int J Oral Maxillofac Surg 1998;27:352-5.

33. Ylikontiola L, Sundqvuist K, Sandor GK, Tormala P, Ashammakhi N. Self-reinforced bioresorbable poly-L/DL-lactide [SR-P(L/DL)LA] 70/30 miniplates and miniscrews are reliable for fixation of anterior mandi- bular fractures: a pilot study. Oral Surg Oral Med Oral Pathol Oral Radiol Endod 2004;97(3):312-7.

34. Yerit KC, Enislidis G, Schopper C, Turhani D, Wanschitz F, Wagner A, Watzinger $F$, Ewers R. Fixation of mandibular fractures with biodegradable plates and screws. Oral Surg Oral Med Oral Pathol Oral Radiol Endod 2002;94:294-300.

35. Tams J, Van Loon JP, Otten B, Bos RRM. A computer study of biodegradable plates for internal fixation of mandibular angle fractures. J Oral Maxillofac Surg 2001; 59:404-7.

36. Hoffmann J, Troitzach D, Gulicher D, Adam C, Reinert S. Significance of biodegradable implants in case of midfacial fractures. Biomed Tech (Berl) 2002;47: 496-9.

37. Haers PE, Suuronen R, Lindqvist C, Sailer HF. Biodegradable polylactic acid plates and screws in orthognatic surgery. / Craniomaxillofac Surg 1998;25:87-91.

38. Turvey TA, Bell RB, Tejera TJ, Proffit WR. The use of self-reinforced biodegradable bone plates and screws in orthognatic surgery. J Oral MaxiIlofac Surg 2002; 60:59-65.

39. Norholt SE, Pedersen TK, Jensen J. Le Fort I miniplate osteosynthesis: a randomizad, prospective study comparing resorbable PLLA/PGA with titanium. Int J Oral Maxillofac Surg 2004;33:245-52.

40. Edwards RC, Kiely KD, Eppley BL. Resorbable PLLA-PGA screw fixation of mandibular sagital split osteotomies. / Craniofac Surg 1999;10:230-6.

41. Edwards RC, Kiely KD, Eppley BL. The fate of resorbable Poly-L-Lactic/Polyglycolic acid (Lactosorb) bone fixation devices in orthognatic surgery. J Oral Maxillofac Surg 2001;59:19-25.

42. Edwards RC, Kiely KD, Eppley BL. Fixation of bimaxillary osteotomies with resorbable plates and screws: Experience in 20 consecutive cases. J Oral Maxillofac Surg 2001;59:271-6.

43. Haers PE, Sailer HF. Biodegradable self-reinforced poly-L/DL-lactide plates and screws in bimaxillary orthognatic surgery: short term skeletal stability and material related failures. / Craniomaxillofac Surg 1998; 26: 363-72.

44. Ferretti C, Reyneke JP. Mandibular, sagital split osteotomies fixed with biodegradable or titanium screws: A prospective, comparative study of postoperative stability. Oral Surg Oral Med Oral Pathol Oral Radiol Endod 2002; 93: 534-7.

45. Laine P, Kontio R, Lindqvist C, Suuronen R. Are there any complications with bioabsorbable fixation devices? A 10 years review in orthognatic surgery. Int J Oral Maxillofac Surg 2004; 33: 240-244.

46. Fuente del Campo A. Estabilidad a largo plazo con placas absorbibles para fijación interna en cirugía ortognática. Cir Ciruj 2003; 71: 93-9.

47. Rubin JP y Yaremchuck MJ. Complications and toxicities of implantable biomaterials used in facial reconstructive and aesthetic surgery: A comprehensive review of the literature. Plast Reconstr Surg 1997; 100: 1336-53.

48. Gerlach KL. In-vivo and clinical evaluations of poly(L-lactide) plates and screws for use in maxillofacial traumatology. Clinical Materials 1993; 13: 21.

49. Schmidt BL, Perrott DH, Mahan D, Kearns G. The removal of plates and screws after Le Fort I osteotomy. I Oral Maxillofac Surg 1998; 56: $184-8$.

50. Tuovinen V, Norholt SE, Sindet-Pedersen S, Jensen J.A retrospective analysis of 279 patients with isolated mandibular fractures treated with titanium miniplates. J Oral Maxillofac Surg 1994; 52: 931-5. 
51. lizuka T, Lindqvist C. Rigid internal fixation of mandibular fractures. An analysis of 270 fractures using the AO/ASIF method. Int J Oral MaxiIlofac Surg 1992; 21: 65-9.

52. Pietrzak WS, Sarver DR, Bianchini SD, D'Alessio K. Effect of simulated intraoperative heating and shaping on mechanical properties of a bioabsorbable fracture plate material. J Biomed Mater Res 1997; 38: 17-24.

53. Tiainen J, Leinonen S, Ilomäki J, Suokas E, Törmälä P, Waris TH, Ashammakhi N. Comparison of the pull-out forces of bioabsorbable polylactide/glycolide screws (Biosorb and Lactosorb) and tacks: A study on the stability of fixation in human cadaver parietal bones. J Craniofac Surg 2002; 13: 538-43.
54. Serlo W, Ashammakhi N, Törmälä P, Waris TH. A new technique for cranial bone osteofixation: Use of bioabsorbable tacks and plates to fix parietal bone split grafts used for reconstruction of a posttraumatic frontal bone defect. / Craniofac Surg 2002; 13: 331-6.

55. Spanio S, Ashammakhi N, llomäki J, Välimaa T, Rainer C, Waris TH, Törmälä P, Ninkovic M. Use of new bioabsorbable tacks and a tackshooter in cranial bone osteofixation saves operative time. / Craniofac Surg 2002; 13: 693-6.

56. Dolanmaz D, Uckan S, Isik K, Saglam H. Comparison of stability of absorbable and titanium plate and screw fixation for sagittal split ramus osteotomy. Br J Oral Maxillofac Surg 2004; 42: 127-32. 